\title{
Termiczne efekty oddziaływania smartfonu na małżowinę uszną
}

\begin{abstract}
Streszczenie. Celem pracy było określenie zmian temperatury oraz zmian skórnych okolic małżowiny usznej związanych z używaniem telefonu komórkowego oraz ustalenie przyczyn ich powstawania. Zmierzony przyrost temperatury na powierzchni ucha po rozmowie telefonicznej jest kombinacją kilku efektów, takich jak zaburzenie konwekcji między skórą a otoczeniem, absorpcji mikrofal przez tkanki czy nagrzewania się elementów telefonu.
\end{abstract}

Abstract. The aim of experiment was the determination of temperature distribution and skin effects of auricle region exposed on smartphones and distinction between influence of EM waves generated by device and other factors affected temperature increase. (Thermal effects of auricle region exposed on smartphones).

Słowa kluczowe: termografia, smartfon, efekty termiczne.

Keywords: infrared thermography, smartphones, thermal effects.

\section{Wstęp}

Telefony komórkowe są obecnie jednym z najbardziej popularnych narzędzi komunikacji. Tylko w samej Polsce notuje się, iż około $92 \%$ dorosłych obywateli korzysta z telefonii mobilnej, a połowa badanych wyłącznie ze smartfonów [1]. Wykorzystywane w transmisji komórkowej promieniowanie niejonizujące wywołuje głównie tzw. efekt termiczny, czyli nagrzewanie się części ciała, a zwłaszcza skóry i jej warstw powierzchniowych, podczas bezpośredniego kontaktu urządzenia z nimi w czasie rozmowy [2].

Skutki zdrowotne związane $z$ tzw. nietermicznym oddziaływaniem promieniowania elektromagnetycznego, pochodzącego od telefonii komórkowej, są przedmiotem badań od wielu lat. Pomimo szeregu doniesień na temat niepożądanych efektów tego promieniowania takich jak: choroby nowotworowe [3-5], nadwrażliwość elektromagnetyczna [6,7], niesprawność czynności układu nerwowego [8], problemy ze snem $[9,10]$, a także upośledzenie czynności rozrodczych [11], nie udało się udowodnić wzrostu zachorowalności na te przypadłości na skutek zwiększonej ekspozycji na pola elektromagnetyczne [12-14]

Efekt termiczny to jeden $\mathrm{z}$ najczęściej badanych skutków korzystania $z$ telefonu komórkowego $[15,16]$. Absorpcja promieniowania elektromagnetycznego w trakcie standardowej rozmowy telefonicznej ma miejsce głównie w warstwach powierzchniowych skóry, skutkiem czego jest jej lokalny wzrost temperatury, który może wywołać wiele skutków pośrednich w organizmie, zarówno na poziomie molekularnym, jak i fizjologicznym. Z drugiej jednak strony istnieje szereg mechanizmów niwelujących te przyrosty temperatury, takie jak odprowadzanie ciepła na drodze konwekcji czy też zwiększony przepływ krwi. Ich zahamowanie może w znacznym stopniu przyczynić się do lokalnego zachwiania równowagi procesów termoregulacji, dających również objawy pod postacią zmian dermatologicznych.

Celem pracy było określenie zmian temperatury okolic małżowiny usznej oraz zmian skórnych związanych z używaniem telefonu komórkowego oraz ustalenie przyczyn ich powstawania. W szczególności badania zostały ukierunkowane na odróżnienie wpływu pola elektromagnetycznego w zakresie mikrofal, generowanego przez urządzenie, od innych efektów fizycznych, np. hamujących transport ciepła z powierzchni skóry.

\section{Materiały i metody}

Badania termograficzne i dermatologiczne okolic głowy i szyi przeprowadzono na grupie 40 pacjentów w wieku od 18 do 65 lat. Dodatkowo przeprowadzono pomiary termograficzne dla grupy 10 ochotników w trybie „flight mode" oraz z wyłączonym aparatem telefonicznym. Pacjenci do badania zgłaszali się około 20 minut przed pomiarem w celu stabilizacji temperatury skóry głowy i szyi. Przed badaniem proszeni również byli o zdjęcie okrycia wierzchniego głowy i szyi. Na 60 minut przed badaniem pacjenci nie spożywali ciepłych ani zimnych napojów, alkoholu, ani nie palili papierosów oraz nie wykonywali intensywnego wysiłku fizycznego. Z grupy badanej wyłączeni zostali pacjenci, u których stwierdzono: przewlekłe choroby zapalne i autoimmunologicze, inne schorzenia dermatologiczne, nowotwory (skóry i ogólne) w okresie ostatnich 5 lat. Każdy pacjent wyraził zgodę na uczestnictwo w badaniach. Kwalifikacja pacjenta do badań i uzyskanie zgody na uczestnictwo w badaniach następowała przed wykonaniem pomiarów, w trakcie rejestracji.

Po stabilizacji temperatury skóry pacjenta w warunkach temperatury pokojowej pacjenci poddawani byli oględzinom dermatologicznym okolic głowy i szyi z wykorzystaniem dermatoskopu o powiększeniu 50x oraz wideodermatoskopu. Uwzględniono obecność oraz stopień intensywności kilku najczęściej występujących zmian skórnych w czterostopniowej skali (0 - brak, 1 - słaby, 2umiarkowany, 3- nasilony). Wizualnie oceniano dolegliwości takie jak: rumień skóry, osutka grudkowo-krostkowa, teleangiektazje czy zaburzenia pigmentacji.

$\mathrm{Na}$ podstawie wywiadu oceniano dolegliwości subiektywne takie jak: świąd skóry, uczucie ciepła skóry oraz jej pieczenie.

Termogramy wykonywano z wykorzystaniem kamery termowizyjnej V-20 (Vigo System, Polska), pracującej w zakresie długości fal $8-12 \mu \mathrm{m}$. Badanie przeprowadzono w klimatyzowanym pomieszczeniu o stałej temperaturze. Termogramy głowy wykonywano w płaszczyźnie czołowej oraz w płaszczyźnie strzałkowej prawej oraz lewej.

Po wykonaniu termogramów następowała 15sto minutowa symulacja rozmowy telefonicznej z wykorzystaniem smartfonu popularnej marki. Parametry techniczne telefonu przedstawiono w Tabeli 1. Telefon zalogowany był w sieci Play i ustawiony na odbieranie i nadawanie sygnału o częstotliwości $1800 \mathrm{MHz}$. 
Tabela 1. Specyfikacja telefonu wykorzystywanego w badaniach termograficznych

\begin{tabular}{cc}
\hline Parametr & Opis \\
\hline Model & Huawei P20 Lite \\
SAR [W kg ${ }^{-1}$ ] & Najwyższa wartość $=0.75$ \\
Wymiary (szerokość x & $71.2 \times 148 \times 7.4 \mathrm{~mm}$ \\
wysokość x grubość) & $145 \mathrm{~g}$ \\
Waga & $3000 \mathrm{mAh}$ \\
Bateria & $4 \times 2.36 \mathrm{GHz}$ ARM Cortex-A53 \\
Procesor &
\end{tabular}

Pacjent trzymał telefon przy prawym bądź lewym uchu w standardowy dla siebie sposób. Po 15 minutach symulacji ponownie wykonywano pomiary termograficzne w tych samych płaszczyznach: czołowej oraz strzałkowej prawej i lewej. Po wykonaniu pomiarów termograficznych dokonywano ponownych oględzin dermatologicznych oraz wywiadu z pacjentem. Wykonywano również zdjęcia zmian skórnych, jeśli takie powstały na skutek ekspozycji.

Dodatkowo, w celu oszacowania wpływu aktywności termicznej telefonu na rozkład temperatury okolic małżowiny usznej, dla grupy 10 ochotników wyznaczono wzrost temperatury dla ucha prawego poddanego ekspozycji od telefonu w trybie „flight mode". Ponadto wykonano również termogramy powyższych okolic po symulacji rozmowy $z$ wyłączonym telefonem $w$ celu weryfikacji zaburzeń odprowadzania ciepła przez skórę na skutek przyłożonego do niej telefonu.

W celu ilościowego oszacowania efektów termicznych powstałych na skutek 15 minutowej rozmowy telefonicznej, obszary małżowiny usznej zarówno ucha eksponowanego jak i nieeksponowanego poddano procedurze segmentacji (konturowania). Przy pomocy programu sterującego kamerą V-20, wyznaczono wartości średnich temperatur z zakreślonego obszaru oraz wyznaczono różnicę średnich temperatur w wyróżnionym obszarze skóry głowy pacjenta przed i po symulacji rozmowy telefonicznej.

Do określenia różnic statystycznych pomiędzy temperatura wyznaczonego obszaru przed i po ekspozycji zastosowano nieparametryczny test KołmogorowaSmirnova na poziomie istotności 0.05 .

\section{Wyniki}

$\mathrm{Na}$ skutek przeprowadzonego wywiadu oraz badania dermatologicznego najczęstszym objawem dermatologicznym występującym u pacjentów po ekspozycji było uczucie ciepła skóry, w okolicy poddanej ekspozycji, które zgłaszało $34 \%$ badanych pacjentów w stopniu słabym, natomiast $5 \%$ pacjentów w stopniu umiarkowanym (Rys.3).

U 29\% pacjentów, w stopniu słabym, a u $21 \%$ w stopniu umiarkowanym po ekspozycji wystapiły teleangiektazje objawiające się jako poszerzone naczynia w małżowinie usznej. Przykładowe zdjęcie teleangiektazji przedstawiono na Rys.1.

U około $16 \%$ pacjentów zaobserwowano również po ekspozycji rumień skóry w stopniu słabym i umiarkowanym u 5\% badanych pacjentów. Przykładowy obraz fragmentu skóry małżowiny usznej $\mathrm{z}$ wideo-dermatoskopu ukazujący rumień pokazano na Rys. 2

Około 3\% pacjentów zgłaszało świąd skóry w okolicach poddanych ekspozycji. Pozostałych efektów nie zaobserwowano.

W celu ilościowego oszacowania efektów termicznych powstałych na skutek 15 minutowej ekspozycji, obszary małżowiny usznej zarówno ucha eksponowanego jak i nieeksponowanego poddano procedurze segmentacji (konturowania). Przy pomocy programu sterujacego kamera V-20, wyznaczono wartości maksymalnych, minimalnych oraz średnich temperatur $\mathrm{z}$ zakreślonego obszaru.
Przykładowe termogramy z wyznaczonym obszarem małżowiny usznej przedstawiono na Rys. 4.
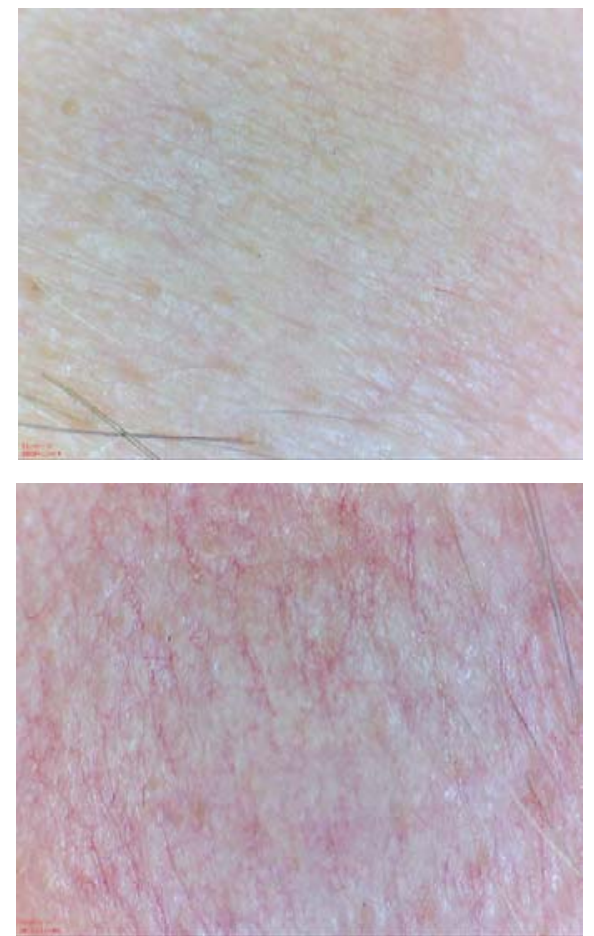

Rys. 1 Obraz fragmentu skóry małżowiny usznej przed ekspozycją (u góry) oraz przedstawiający poszerzone naczynia po ekspozycji (u dołu)
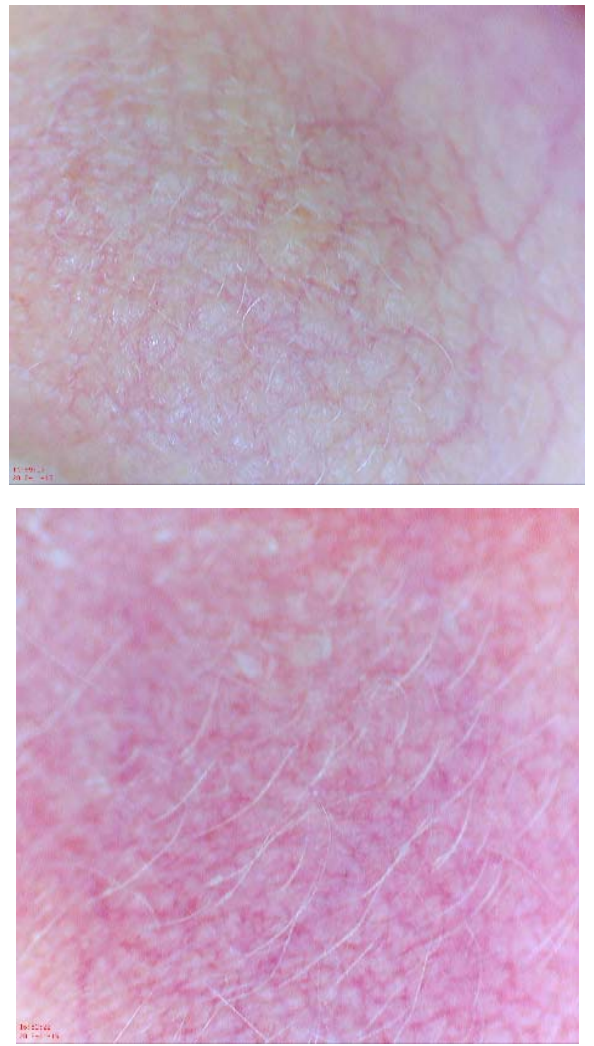

Rys. 2 Obraz fragmentu skóry małżowiny usznej przed ekspozycją (po lewej) oraz rumień po ekspozycji (po prawej)

W celu oszacowania średniego przyrostu temperatury w trakcie ekspozycji oszacowano różnicę temperatur $w$ wyznaczonym obszarze przed i po symulacji rozmowy 
telefonicznej. W Tabeli 2, przedstawiono parametry statystyczne średnich wartości przyrostu temperatury.

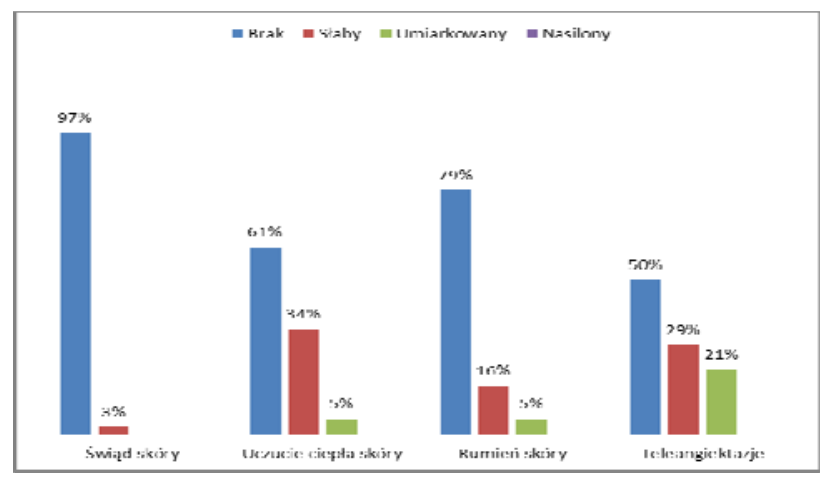

Rys. 3 Wykres przedstawiający wynik badania dermatologicznego

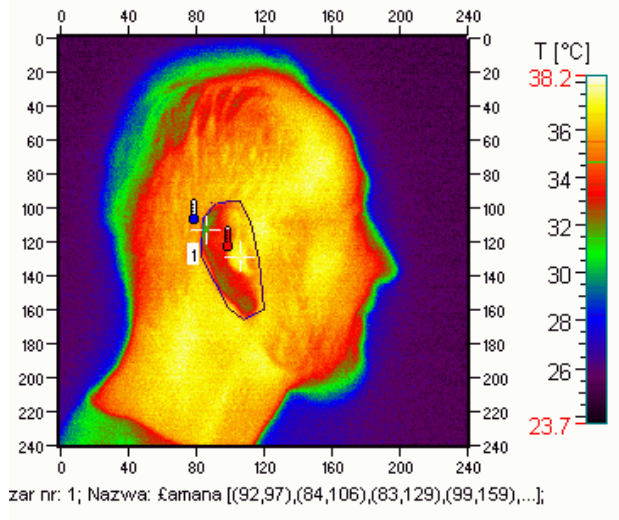

Temp. $\left[{ }^{\circ} \mathrm{C}\right]$ : Min $=31.22 ;$ Maks $=37.84 ;$ CEred $=34.47$;

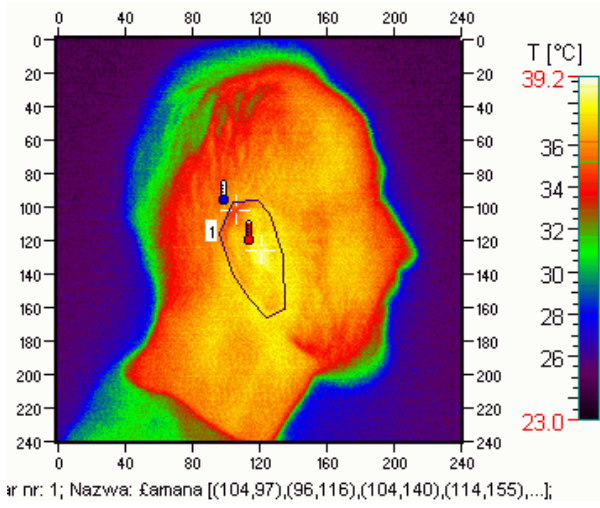

Rys. 4 Termogramy ucha prawego przed (u góry) i po rozmowie telefonicznej (u dołu)

Tabela 2. Parametry statystyczne średnich wartości przyrostu temperatury.

\begin{tabular}{|c|c|c|c|}
\hline Parametr & $\begin{array}{c}\Delta \mathrm{T} \text { poddane } \\
\text { ekspozycji } \\
{\left[{ }^{0} \mathrm{C}\right]}\end{array}$ & $\begin{array}{c}\Delta \mathrm{T} \text { ucho } \\
\text { referencyjne } \\
{\left[{ }^{0} \mathrm{C}\right]}\end{array}$ & $\begin{array}{c}\Delta \mathrm{T} \text { twarz } \\
{\left[{ }^{0} \mathrm{C}\right]}\end{array}$ \\
\hline Średnia $\left[{ }^{\circ} \mathrm{C}\right]$ & 1,87 & 0,37 & 0,69 \\
\hline $\begin{array}{c}\text { Odchylenie } \\
\text { standardowe }\left[{ }^{\circ} \mathrm{C}\right]\end{array}$ & 1,12 & 0,75 & 0,79 \\
\hline
\end{tabular}

Tabela 3. Wyniki testu statystycznego Kołmogorova-Smirnova.

\begin{tabular}{|c|c|c|c|}
\hline $\begin{array}{c}\text { Parametr }(\alpha= \\
0.05)\end{array}$ & ucho prawe & ucho lewe & twarz \\
\hline Wartość $p$ & $<0.05$ & 0.24 & 0.08 \\
\hline
\end{tabular}

Z Tabeli 3 wynika, iż na poziomie istotności $\alpha=0.05$, nie ma statystycznie istotnych różnic pomiędzy średnimi wartościami temperatur z wyznaczonych obszarów na termogramach przed i po ekspozycji dla ucha referencyjnego oraz twarzy. Statystycznie istotna różnica występuje natomiast dla średnich temperatur wyznaczonych z obszarów ucha poddanego ekspozycji przed i po symulacji rozmowy telefonicznej.

Dodatkowo, w celu oszacowania wpływu mikrofal na ogrzewanie okolic małżowiny usznej dla grupy ochotników wyznaczono wzrost temperatury dla ucha prawego poddanego ekspozycji od telefonu w trybie „flight mode" oraz telefonu wyłączonego. Wyniki przedstawiono w Tabeli 4.

Tabela 4. Parametry statystyczne średnich wartości przyrostu temperatury - ucho prawe -3 tryby

\begin{tabular}{|l|l|l|l|}
\hline Parametr & $\begin{array}{l}\Delta \mathrm{T} \text { prawe }\left[{ }^{0} \mathrm{C}\right] \\
- \text { normalny }\end{array}$ & $\begin{array}{l}\Delta \mathrm{T} \text { prawe } \\
{\left[{ }^{0} \mathrm{C}\right]-\text { flight }} \\
\text { mode }\end{array}$ & $\begin{array}{l}\Delta \mathrm{T} \text { prawe } \\
{\left[{ }^{0} \mathrm{C}\right]} \\
\text { wyłączony }\end{array}$ \\
\hline Średnia $\left[{ }^{\circ} \mathrm{C}\right]$ & $1,87 \pm 0,18$ & $1,10 \pm 0,17$ & $0,67 \pm 0,15$ \\
\hline $\begin{array}{l}\text { Odchylenie } \\
\text { standardowe }\left[{ }^{\circ} \mathrm{C}\right]\end{array}$ & 1,12 & 0,75 & 0,50 \\
\hline
\end{tabular}

Wyniki testu Kołmogorova-Smirnova sprawdzającego różnice przyrostu temperatury w poszczególnych trybach pracy telefonu przedstawiono w Tabeli 5.

Tabela 5. Porównanie statystyczne pomiędzy różnymi trybami pracy telefonu - ucho prawe

\begin{tabular}{|c|c|c|c|}
\hline $\begin{array}{c}\text { Parametr }(\alpha= \\
\text { 0.05) }\end{array}$ & Flight - wył & Fight - normal & $\begin{array}{c}\text { Wył - } \\
\text { normal }\end{array}$ \\
\hline Wartość $p$ & 0,16 & 0,13 & 0.02 \\
\hline
\end{tabular}

Z Tabeli 5 wynika, iż na poziomie istotności $\alpha=0.05$, nie ma statystycznie istotnych różnic pomiędzy trybem „flight mode”, a telefonem wyłączonym oraz pomiędzy trybem "flight mode", a telefonem pracującym na pełnym obciążeniu. Statystycznie istotna różnica występuje natomiast dla średnich temperatur wyznaczonych $z$ obszarów ucha poddanego ekspozycji dla trybu normalnego oraz telefonu wyłączonego.

\section{Wnioski}

W badaniu dermatologicznym stwierdzono, iż najczęstszym objawem powstałym na skutek 15 minutowej rozmowy telefonicznej są telenagiektazje wtórne, czyli widoczne zmiany w układzie naczyniowym skóry, powstałe na skutek czynnika zewnętrznego - lokalnego wzrostu temperatury $\mathrm{w}$ badanym obszarze małżowiny usznej. Objawy te zdiagnozowano u $50 \%$ badanych pacjentów. Wzrost temperatury w obszarze eksponowanym był także przyczyną występowania rumienia skóry, który odnotowano u około $21 \%$ badanych pacjentów.

Oprócz wyżej opisanych objawów stwierdzonych przez lekarza dermatologa, około $39 \%$ pacjentów zgłaszało uczucie ciepła w miejscu eksponowanym, natomiast $3 \%$ z nich zgłaszało świąd skóry. Należy jednak podkreślić, iż zarówno uczucie ciepła jak i świąd są dolegliwościami subiektywnymi. Wszystkie efekty dermatologiczne są charakterystyczną odpowiedzią mechanizmów termoregulacji organizmu na lokalny wzrost temperatury oraz wynikiem ucisku aparatu telefonicznego na skórę małżowiny usznej. Należy jednak podkreślić, iż wskazane dolegliwości ustąpiły po kilkunastu minutach po ekspozycji.

W badanym obszarze powierzchni małżowiny usznej dla ucha poddanego ekspozycji zanotowano istotny statystycznie przyrost temperatury średnio o $1.87 \pm 0.18{ }^{\circ} \mathrm{C}$, w porównaniu do tego samego obszaru przed ekspozycją. Przyrost temperatury w obszarze eksponowanym charakteryzował się dużym rozrzutem (odchylenie standardowe $=1.12{ }^{\circ} \mathrm{C}$ ) i zależy od wartości rozkładu 
temperatury początkowej $(r=-0.63 . p<0.05)$. Niższa wartość początkowa wywołuje większy przyrost temperatury.

Według powszechnie dostępnej literatury średni przyrost temperatury w obszarze małżowiny usznej zależy od typu zastosowanego smartfonu i wynosi pomiędzy 1.2 , a $2.3^{\circ} \mathrm{C}$ dla ucha poddanego ekspozycji przez 35 minut [15], pomiędzy 1.2 , a $1.8{ }^{\circ} \mathrm{C}$ po 40 minutowej ekspozycji [16] oraz $0.83{ }^{0} \mathrm{C}$ po 5 - minutowej rozmowie [17]. Taki wzrost temperatury teoretycznie, może wywołać wiele skutków pośrednich, należy jednak zaznaczyć, iż zanotowano go na powierzchni skóry, a szybkość wytwarzania ciepła w tkance jest odwrotnie proporcjonalna do kwadratu głębokości penetracji.

Pomiary termograficzne z wykorzystaniem trybu „flight mode" miały na celu oszacowanie wpływu aktywności termicznej telefonu na ogrzewanie ucha. Wykazano przyrost temperatury powierzchni małżowiny usznej średnio o $1.10 \pm 0.17{ }^{\circ} \mathrm{C}$ i statystycznie przyrost ten nie różni się od średniego przyrostu temperatury $\mathrm{z}$ użyciem telefonu $\mathrm{w}$ trybie normalnym $(p=0.13)$ oraz $w$ telefonie wyłączonym $(p=0.16)$.

Wyniki pomiarów z telefonem wyłączonym przyłożonym do ucha wskazują na lokalny wzrost temperatury małżowiny usznej o $0.67 \pm 0.15{ }^{\circ} \mathrm{C}$ i wynik ten statystycznie różni się od telefonu pracującego $\mathrm{w}$ trybie normalnym, natomiast nie wykazuje istotnej statystycznie różnicy od przyrostu temperatury w trybie „flight mode”. Uzyskane wartości zmierzonych przyrostów temperatury nie przekroczyły $2^{0} \mathrm{C}$ na powierzchni skóry. Znacznie wyższe przyrosty można zaobserwować w życiu codziennym.

Zmierzony przyrost temperatury na powierzchni ucha po rozmowie telefonicznej jest kombinacja kilku efektów, objawiających się przyrostem temperatury na powierzchni badanych obszarów. Zarejestrowana zmiana temperatury badanego fragmentu małżowiny usznej jest wynikiem działania:

- upośledzonego odprowadzania ciepła w procesie konwekcji przez skórę na skutek przyłożonego do ucha telefonu (średni przyrost temperatury $0.67 \pm 0.2{ }^{\circ} \mathrm{C}$ ).

- aktywności elementów telefonu (nagrzewająca się bateria, procesor itd.) stanowiących dodatkowe źródło ciepła, a przy tym dodatkowo zaburzających jego konwekcyjny transport,

- absorpcji przez tkankę mikrofal generowanych przez antenę telefonu.

Jednak brak statystycznie istotnych różnic pomiędzy przyrostem temperatur w trybie "flight mode" a trybem normalnym może sugerować brak udziału promieniowania mikrofalowego w zmianie temperatury tkanki. Dopiero połączenie wszystkich trzech efektów wykazało istotne statystycznie różnice dla tej grupy pacjentów.

Autorzy: dr Tomasz Rok, Zakład Biofizyki, Katedra Fizjologii, Wydział Lekarski, Uniwersytet Jagielloński Collegium Medicum, ul. Łazarza 16, 31-530 Kraków, E-mail: tomasz.rok@uj.edu.pl; Lek. med. Karolina Basta-Klonowska, Oddział Kliniczny Dermatologii, Szpital Uniwersytecki w Krakowie, ul. Skawińska 8 31-066 Kraków, E-mail: basta.k@wp.pl; dr hab. Grzegorz Tatoń, Zakład Biofizyki, Katedra Fizjologii, Wydział Lekarski, Uniwersytet Jagielloński Collegium Medicum, ul. Łazarza 16, 31-530 Kraków, E-mail: g.taton@uj.edu.pl; dr Bartosz Lisowski, Zakład Biofizyki, Katedra Fizjologii, Wydział Lekarski, Uniwersytet Jagielloński Collegium Medicum, ul. Łazarza 16, 31-530 Kraków, E-mail: tomasz.rok@uj.edu.pl; Prof. dr ha. Eugeniusz Rokita, Zakład Biofizyki, Katedra Fizjologii, Wydziat Lekarski, Uniwersytet Jagielloński Collegium Medicum, ul. Łazarza 16, 31-530 Kraków, Email: e.rokita@uj.edu.pl;

\section{LITERATURA}

[1] komunikat CBOS „Korzystanie z telefonów komórkowych”, sierpień 2017 (oprac. Michał Feliksiak).

[2] Bauer J., O'Mahony C., Chovan D., Mulcahy J., Silien C., Tofail S. A. M., Thermal effects of mobile phones on human auricle region, J. Therm. Biol.,79 (2019), 56-68

[3] Carlberg M, Hedendahl L, Ahonen M, Koppel T, Hardell L. Increasing incidence of thyroid cancer in the Nordic countries with main focus on Swedish data. BMC Cancer, 16 (2016), 426

[4] Chapman S, Azizi L, Luo Q, Sitas F. Has the incidence of brain cancer risen in Australia since the introduction of mobile phones 29 years ago? Cancer Epidemiol. Elsevier Ltd, 42 (2016), 199-205.

[5] Coureau G, Bouvier G, Lebailly P, Fabbro-Peray P, Gruber A, Leffondre $\mathrm{K}$, et al. Mobile phone use and brain tumours in the CERENAT case-control study. Occup Env Med., (2014), 51422.

[6] Gruber MJ, Palmquist E, Nordin S. Characteristics of perceived electromagnetic hypersensitivity in the general population. Scand J Psychol., 59 (2018), n4, 422-7

[7] Bogers RP, van Gils A, Clahsen SCS, Vercruijsse W, van Kamp I, Baliatsas C, et al. Individual variation in temporal relationships between exposure to radiofrequency electromagnetic fields and non-specific physical symptoms: A new approach in studying 'electrosensitivity.' Environ Int., 121 (2018), 297-307.

[8] Schoeni A, Roser K, Röösli M. Memory performance, wireless communication and exposure to radiofrequency electromagnetic fields: A prospective cohort study in adolescents. Environ Int. Elsevier Ltd., 85 (2015), 343-51.

[9] Danker-Hopfe H, Dorn H, Bolz T, Peter A, Hansen ML, Eggert $T$, et al. Effects of mobile phone exposure (GSM 900 and WCDMA/UMTS) on polysomnography based sleep quality: An intra- and inter-individual perspective. Environ Res. Elsevier., 145 (2016), 50-60.

[10] Huss A, Van Eijsden M, Guxens M, Beekhuizen J, Van Strien $\mathrm{R}$, Kromhout $\mathrm{H}$, et al. Environmental radiofrequency electromagnetic fields exposure at home, mobile and cordless phone use, and sleep problems in 7-year-old children. PLoS One. 2015;10(10):1-14.

[11] Agarwal, A., Deepinder, F., Sharma, R.K., Ranga, G., Li, J., Effect of cell phone usage on semen analysis in men attending infertility clinic: an observational study.Fertil. Steril. 89 (2008), 124-128.

[12] Luo J., Deziel N.,C., Huang H., Chen Y., Ni X., Ma S., Udelsman R., Zhang Y.,Cell phone use and risk of thyroid cancer: a population-based case-control study in Connecticut, Annals of Epidemiology, 29 (2019), 39-45

[13] Meena JK, Verma A, Kohli C, Ingle GK. Mobile phone use and possible cancer risk: Current perspectives in India. Indian $J$ Occup Environ Med. India: Medknow Publications \& Media Pvt Ltd, 20 (2016), 5-9.

[14] Verrender A, Loughran SP, Anderson V, Hillert L, Rubin GJ, Oftedal G, et al. IEI-EMF provocation case studies: A novel approach to testing sensitive individuals. Bioelectromagnetics. 39 (2018), 132-43.

[15] Kargel C. Infrared thermal imaging to measure local temperature rises caused by handheld mobile phones. IEEE Trans Instrum Meas. 54 (2005),1513-9.

[16] Lahiri BB. Bagavathiappan S. Soumya C. Jayakumar T. Philip $\mathrm{J}$. Infrared thermography based studies on mobile phone induced heating. Infrared Phys Technol. 71 (2015), 242-51

[17] Bauer. J., Górecki. I., Kohyt. M., Migasiewicz A., Podbielska $\mathrm{H}$., The influence of smartphones' operation modes on the superficialtemperature distribution in the human auricle region $\mathrm{J}$ Therm Anal Calorim 133 (2018), 559. 